\title{
Characteristics of Titounis Children Songs: A Study of Songs, Music Instruments and Onomatopoeia
}

\author{
Mochammad Usman Wafa ${ }^{\bowtie}$, Neli Purwani, Abdul Malik \\ Universitas Negeri Semarang, Indonesia
}

Submitted: August 4, 2020. Revised: October 9, 2020. Accepted: November 4, 2020

\begin{abstract}
The purpose of the study is to describe an analysis of children's song characteristics Titounis. This study used a musicological approach to recognize songs' characteristics. The data collection were document study and, listen and take note. This study used a content analysis technique. The analysis cover three aspects: (1) songs' analysis, (2) instruments' analysis, (3) Onomatopoeia. The songs that were analyzed were (1) Petit Escargot, (2) Le Roues de 1 Autobus, (3) Les Chiffres, (4) Un kilometer en Roulant. In the song analysis, the patterns used were general patterns, using fun and cheerful vocals, strong tonal stress, relatively limited variations in tones, slow, fast, and gradual tempo. The delivery style invites singing as well as dialogue or interaction. Then in musical instruments, the melody variations of each instrument form harmonization, the use of non-musical instruments emphasizes the theme of the song and provides the experience of hearing about the environment. The onomatopoeic analysis shows sound vroom (car), pataboum (jumping passengers), bip-bip-bip (serine), suisse-suisse (wiper). The onomatopoeia of Titounis songs serves to strengthen the song's theme.
\end{abstract}

Keywords: Titounis children song; onomatopoeia

How to Cite: Wafa, M. U., Purwani, N., \& Malik, A. (2020). Characteristics of Titounis Children Songs: A Study of Songs, Music Instruments and Onomatopoeia. Harmonia: Journal of Arts Research And Education, 20(2), 161-166

\section{INTRODUCTIONS}

Qualified education at an early age is sought to encourage the development of various intelligence domains and is also carried out through various stimuli. Education at an early age is developed with principles, one of which is to invite learning in a fun way. One form of learning in this fun way is done through song or chanting.

Frobel argues that students should be given a lot of singing experience through singing and playing activities (Sumaryanto \& Utomo, 2015). Singing activities for children have been carried out for va- rious purposes, including calming fussy children, putting them to sleep, inviting learning, and playing. Babies prefer consonants to hear dissonances, regardless of the circumstances of the previous parents (Masataka, 2006). Children can also capture messages through the musical characteristics of adults, and that is what is called the language of music (Trainor, 2019). Another study has shown that fast-paced music results in an increase in brain activity (Lehmann, \& Seufert, 2017; Nicolaou, et al., 2017). It is therefore not surprising that musical training sharpens the initial coding of sounds to the brain leading to increased performance on various listening

${ }^{\triangle}$ Corresponding author:

E-mail: usmanwafa@mail.unnes.ac.id 
skills (Hyde, et al., 2009).

Singing activities in early childhood is a universal activity, carried out by various nations with different cultural backgrounds. It can be seen that in the internet era, children's songs were developed for various purposes. Kristyana \& Suharto (2014) state in their study that from the lyrics of the children's songs, children gain high sensitivity towards the sounds of language, and in the next stage of their age, children will realize the functions and the power of words. On YouTube, we can find several channels that focus on developing children's songs, Pinkfong from Korea, Super Simple Songs from America, and Titounis from France. These different cultures underlie the development of children's songs. By listening at a glance, Titounis' songs invite children to sing at the same time to dialogue or interact. Super Simple Song songs are more inviting to sing while on Pinkfong's songs, music is used only as an accompaniment so that it gives the impression that children only practice singing. Skills, attitudes, moods, environment, and interpersonal relationships can also modify music processing (Hernandez-Ruiz, 2019).

The varied instrumentation of accompaniment by utilizing imitations of sound combined with very simple song lyrics makes the presentation of Titounis songs different from songs from other children's music video channels. Such a pattern needs to be studied to determine its potential if used as material for children's songs that can positively contribute to children's development. However, music is an audible art, with aspects of meaning that cannot be understood only in symbolic terms. In line with this, Huron said, there are nine general emotions (transcendent, tenderness, sadness, nostalgia, peace, strength, joy, enthusiasm, and tension) caused by the music (Huron, 2011). Therefore, the music evokes a picture of experience (Reybrouck, 2015).

The results of the study (Intani, 2012; Wahyuni, 2012) emphasize the power of lyrics in the meaning of the message of the song conveyed. Predictable reading of text, grouping words so that lyrics can be matched with music, or recognizing patterns that have been sounded, is one explanation as an effort to increase literacy after musical activities (Butzlaff, 2000; Forgeard, et al., 2008). Meanwhile, Ekaningrum and Suharto (2015) revealed that most of A.T. Mahmud's songs have themes about everyday life according to children's characteristics and world. Children's songs use language suitable for children's development, so they are easy to do and memorize.

Therefore, it is not uncommon for children's songs to use onomatopoeia which refers to the naming of objects or actions with imitation of sounds associated with objects or actions; in other words, sound imitations to manifest, show, various manifest sounds. (Kridalaksana, 2013).

Based on the characteristics of the children's world, this study explores the characteristics of Titounis children's songs, including aspects of songs, musical instruments, imitations of sounds that are pronounced, and adapted into the song's contents.

\section{METHODS}

This study uses a musicological approach, with qualitative data presentation. The study's focus is on Titounis children's songs with the theme 'Transportation (Vroom Vroom)'. Analysis of these songs is based on YouTube media, selected four songs containing many musical instruments and imitations of the sounds delivered. The songs are Petit Escargot, Le Roues de 1 Autobus, Les Chiffres, Un kilometer en Roulant.

The data collection technique uses a document study (music recordings) and listens and takes notes. The data of this research uses content analysis, which considers that all kinds of message production are text, such as news, advertisements, soap operas, songs, and other symbols cannot be separated from the message maker's interests. (Kriyantono, 2012), it is therefore used to show and analyze songs, 
musical instruments, and onomatopoeia.

\section{RESULTS AND DISCUSSION}

The video of Titounis' songs is about transportation; although some of the songs sung are about animals and numbers, the video is shown using transportation visualization. This section will explain songs, musical instruments and onomatopoeia (sound imitation) in the song Petit Escargot, Le Roues de l'autobus, Les Chiffres, Un kilometre en Roulant.

\section{Song Analysis}

The first song is the Petit Escargot song, which consists of 8 bars, repeated 4 times

Petit Escargot

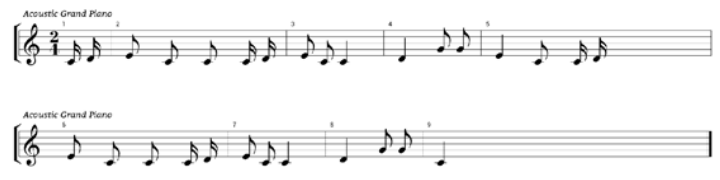

Lyrics

Petit escargot, il porte sur son dos sa maisonnette aussitot qu'il pleut, il est tout heureux il sorte sa tete

The Petit Escargot song repeats two melodic phrases; bars 1-5 are antecedents, and bars 5-9 are consequent. The singing style of the Petit Escargot song looks like a spoken word; the impression of the sound conveyed by the vocals does not try to display a good sound production. Tones sounded in the tone range $\mathrm{c} 1$ - g1. Based on the pronunciation of the lyrics, the song uses the rhyme $\mathrm{a} b \mathrm{~b}$ a. The song Petit Escargot introduces a slow-moving snail visualized as a police car that runs slowly when it's drizzling. The pattern used is the general pattern, using a pleasant and cheerful voice, intense tonal stress, relatively limited tone variations, slow tempo, and style that invites dialogue. (Trainor, 2019).

The Second song is Le Roues de 1 Autobus
Le Roues de 1 Autobus

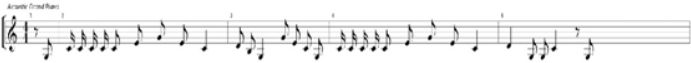

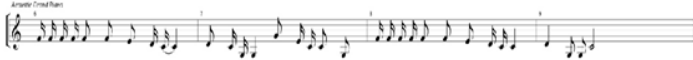

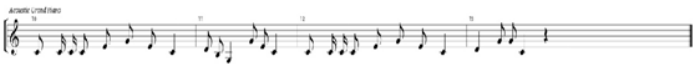

This 13 bar track consists of 2 phrases. This famous song is a French version of the song The Wheel on The Bus, it's just that the phrases in bars 5 to 9 are consequent phrases, so this song has developed from the original song. Rhythmic repetition occurs with each phrase. The tempo used is $120 \mathrm{bpm}$ allegretto. The intonational expression when singing this song is done in staccato. In accordance with the child's speaking style, vibrations are not found in the vocals in this song, which gives a natural impression.

The third song is Les Chiffres

The following is the song's notation. Les Chiffres
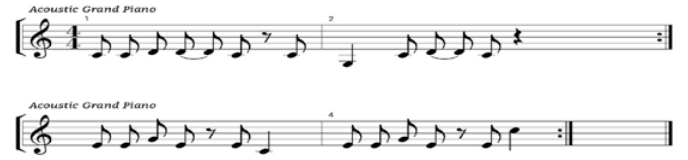

Lyric

Un deux trois quatre cinq six sept huit neuf dix

Le un est un petit train

Le un est un petit train

The song Les Chiffres consists of two phrases; this song is repeated ten times. Rhythmic repetition occurs with each phrase. The tempo used is moderato 118 bpm (beat per minute). This song introduces the numbers 1 to 10 , each number indicating the type of transportation, such as a small train, a blue car, and a ship. Based 
on the pronunciation of the lyrics, the song uses the rhyme $a$ a $a$ a. The style in singing this song is like a child talking in the c1 - c2 tone range. When on the tenth repetition, the tempo of this song gets faster until it approaches presto.

The fourth son gis Un kilometre en Roulant

The following is the song's notation. Un kilometre en Roulant

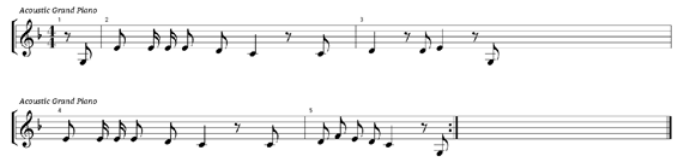

Lyric

Un kilometre en roulant

C'est long c'est long

Un kilometre en roulant

C'est long pour les enfants

This song is different from other songs, which uses the basic tone of F. The song Un kilometer en Roulant uses an allegretto tempo of $120 \mathrm{bpm}$. This song is only 4 bars, consisting of antecedents and consequences. Besides introducing transportation, this song introduces numbers and units of distance traveled (kilometers). Based on the pronunciation, this song uses rhyme $a$ a $a$ a.

Table 1. Music Instrumentation Analysis.

\begin{tabular}{cc}
\hline \multicolumn{2}{c}{ The sound of a musical instrument } \\
\hline $\begin{array}{c}\text { Musical } \\
\text { Instrument }\end{array}$ & Non Musical instrument \\
\hline Flute & Drizzle \\
Bass & Bird \\
Piano & Sirene \\
String & Car (engine, horn) \\
Percussion & Airplane, Helicopter \\
Dirt Guitar & Whistle \\
Drum & Motorcycle \\
& Ambulance \\
\hline
\end{tabular}

Based on the Table 1, musical instrument sounds consist of seven musical instruments, both melodic, harmonic, and percussive. Based on these songs, the tools are played alternately. Variations in the melody (pitch value and pitch) of each instrument form a harmonization, not overlapping, so that it creates an impression that is not monotonous. The presentation is as follows:

For example, in the Petit Escargot song, the music starts with a flute, followed by a bass and a xylophone sound following the song lyrics. The visible non-musical instruments such as drizzle, cars, sirens sound alternately from the beginning to the end of the song. The sound of birds, sirens, and cars is used to emphasize the theme and give a natural impression so that the use of non-musical instrument sounds provides a listening experience environment. Alternate use of musical instruments and non-musical instrument support is also carried out on other songs. So that it becomes one of the characteristics of Titounis children's songs

Titounis songs use a fixed and regular tempo. However, in the Le Chiffres song, the slow tempo used is gradually fast; music with a fast beat and rhythm that invites jumping can be said to be happy music. (Delalande, 2003; Meng \& Jiang, Jiani, Fangfang Liu, 2020). However, the other songs presented also use a slow tempo and tell stories of fun and joy. This shows that tempo is not only a physical characteristic of the music, but more than that, namely, the message conveyed through sound leads to different emotions.

\section{Onomatopoeic Analysis}

The use of onomatopoeia or sound imitations in Titounis songs with the theme of transportation appears most frequently in Le Roues de 1 Autobus's song. Other songs use only one sound imitation (vroom).

In its use, the imitation of the vroom vroom sound is pronounced on a vowel that indicates a car is running, then pataboum is pronounced when the bus passenger moves to jump from the seat until a collision occurs, then a beep beep, pronounced in a vowel indicating that the horn is sounding. Onomatopoeia is word formed as a result of sound imitation. The names of objects or 
things are formed based on the sound of the object or the sound generated from the object (Chaer, 2009). In the Titounis song, onomatopoeia functions to strengthen the song's theme by not using musical instruments but using onomatopoeia, which is a form of human language. The existence of onomatopoeia also reinforces the impression of inviting dialogue.

Table 2. The onomatopoeia contained in the Titounis song with the theme of transporta-

$$
\text { tion. }
$$

\begin{tabular}{cc}
\hline \multicolumn{2}{c}{ Onomatopoeia } \\
\hline Car & Vroom \\
Passenger on the bus & Pataboum \\
Bus Wiper & Suisse suisse suisse \\
Horn/sirine & Bip bip bip \\
\hline
\end{tabular}

\section{CONCLUSION}

The song Titounis is a French song that introduces simple things to children. The songs being analyzed are (1) Petit Escargot, (2) Le Roues de 1 Autobus, (3) Les Chiffres, (4) Un kilometer en Roulant. In the song analysis, the patterns used are general patterns, using fun and cheerful vocals, strong tonal stress, relatively limited variations in tones, slow, fast and gradual tempo, then the delivery style invites singing as well as dialogue or interaction. Then in musical instruments, the melody variations of each instrument form a harmonization; non-musical instruments emphasize the theme of the song and provide the experience of hearing about the environment. Onomatopoeic analysis showed the sound of vroom (car), pataboum (jumping passenger), beeps (horn), suissesuisse (wiper). The onomatopoeia of the Titounis song serves to strengthen the song's theme.

\section{REFERENCES}

Butzlaff, R. (2000). Can music be used to teach reading? Journal of Aes- Thetic Education, 34, 167-178.

Chaer, A. (2009). Pengantar Semantik Bahasa
Indonesia (2nd ed.). Rineka Cipta.

Delalande, F. (2003). La Musique Est Un Jeu D'enfant (2nd ed.). Institut National de l'Audiovisuel and Buchet/Chastel.

Forgeard, M., Winner, E., Norton, A., \& Schlaug, G. (2008). Practicing a musical instrument in childhood is associated with enhanced verbal ability and nonverbal reasoning. PLoS One, $3(10)$.

Hernandez-Ruiz, E. (2019). How is music processed? Tentative answers from cognitive neuroscience. Nordic Journal of Music Therapy, 28(4), 315-332.

Huron, D. (2011). Why Is Sad Music Pleasurable? A Possible Role for Prolactin. Musicae Sci., 15, 146-158.

Hyde, K.L., Lerch, J., Norton, A., Forgread, M., Winner, E., Evans, A. C. (2009). Musical Training Shapes Structural Brain Development. The Journal of Neuroscience, 29(10), 3019-3025.

Kridalaksana, H. (2013). Kamus Linguistik (4th ed.). Jakarta: Gramedia Pustaka.

Kristyana, L. N., \& Suharto, S. (2014). Singing as a Strategy to Enhance the Ability to Speak for Early Childhood. Harmonia: Journal of Arts Research and Education, 14(2), 123-130.

Kriyantono, R. (2012). Teknik Praktis Riset Komunikasi (6th ed.). Kencana. Prenadamedia Group.

Lehmann, J.A.M.; Seufert, T. (2017). The Influence of Background Music on Learning in the Light of Different Theoretical Perspectives and the Role of Working Memory Capacity. Front. Psychol., 8, 1902.

Masataka, N. (2006). Preference for Consonance over Dissonance by Hearing Newborns of Deaf parents and of Hearing Parents. National Library of Medicine, 9(1).

Meng, Q., \& Jiang, Jiani, Fangfang Liu, and X. X. (2020). Effects of the Musical Sound Environment on Communicating Emotion. International Journal of Environmental Research and Public Health, 17, 2499.

Nicolaou, N.; Malik, A.; Daly, I.; Weaver, 
J.; Hwang, F.; Kirke, A.; Roesch, E.B.; Williams, D.; Miranda, E. R. ., \& Nasuto, S. J. (2017). Directed Motor-Auditory EEG Connectivity Is Modulated by Music Tempo. Front. Hum. Neurosci, 11, 502.

Reybrouck, M. (2015). Music as Environment: An Ecological and Biosemiotic Approach. Behavioral Sciences, 5(1).

Sumaryanto, T., \& Utomo, U. (2015). Form, Development And The Application
Of Mudic Media In The Kindergarden: A Comparative Study of Two Kindergartens. Harmonia: Jurnal Pengetahuan Dan Pemikiran Seni, 15(2), 101-106.

Trainor, L. J. (2019). La Musique chez les tout-petits: Developpement Emotionnel, Auto-Regulation et Cooperation Sociale. Revue Internationale D'education de Sevres, 75, 65-74. 